\title{
Firearms, Violence, and the Potential Impact of Firearms Control
}

\author{
Franklin E. Zimring
}

$\mathrm{T}$ his paper organizes the question of gun controls as violence policy under two quite different headings. The first issue to be discussed is the relationship between gun use and the death rate from violent crime. The second question is whether and how firearms control strategies might reduce the death rate from violence. When we review the evidence on the relationship between guns and violence, it seems clear that gun use, usually handgun use, increases the death rate from violence by a factor of three to five. Nobody in mainstream social science or criminology argues against such weapon effects these days, although some are more skeptical of the magnitude estimated than others (one example is Lance Stell; please see his essay in this issue). ${ }^{1}$ Thus the problem is both genuine and important. When we review the extent to which particular approaches to controlling firearms might reduce the death rate from violence, the evidence for modern attempts at gun control saving lives is much weaker than the evidence that gun use causes death. So gun control is a potential life-saving tool but only if the use of guns in attack can be reduced, and achieving that in our city streets will neither be easy or cheap.

\section{GuN USE AND Violince}

It is not true that guns are used in most criminal events, nor can we say that guns are employed in most violent crimes. Figure 1, adapted from an earlier publication, tells the relevant story.

Guns are only used in $4 \%$ of all crimes, and only $20 \%$ of all violent crimes, but about $70 \%$ of all criminal killings. This tells us immediately what the special problem of gun

Journal of Law, Medicine E Ethics, 32 (2004): 34-37.

(C) 2004 by the American Society of Law, Medicine \& Ethics.

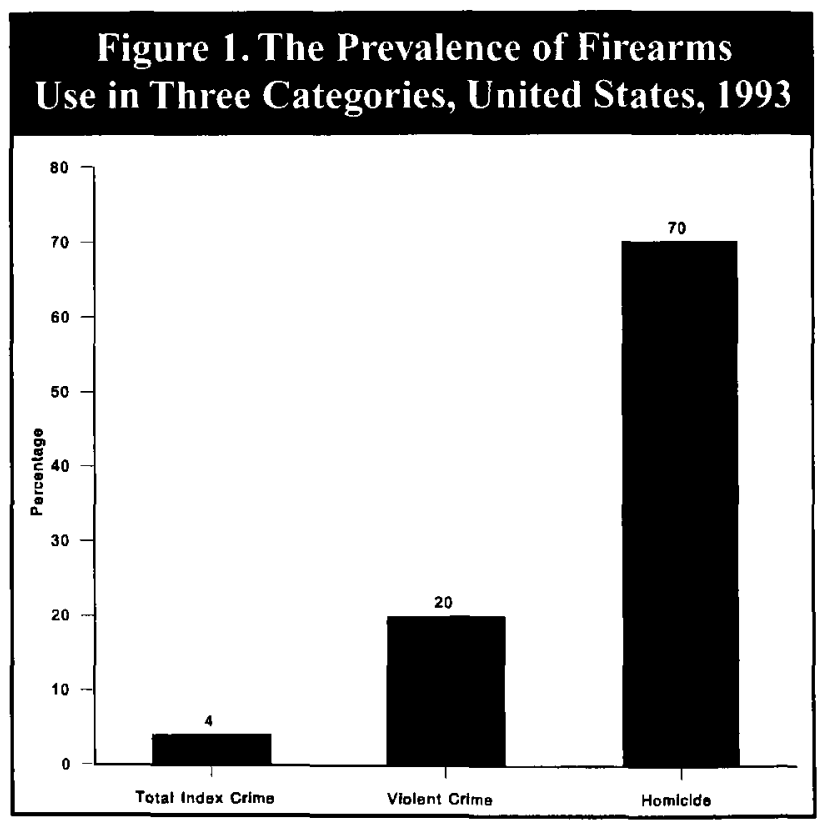

Source: U.S. Department of Justice, Federal Bureau of Investigation, 1993.

use is in violent crime - an increase in the death rate per 100 violent attacks. If the problem you worry about is crime, guns are involved in $4 \%$ of the acts. If the problem is lethal violence, the market share for firearms is $70 \%$. Guns alone account for twice as many criminal deaths as all other means of killing combined. Why is that?

Most criminal homicides result from violent assaults without any other criminal motive such as robbery or rape. Gun assaults are seven times as likely to kill as all other kinds of criminal assault, ${ }^{2}$ and about five times as likely to kill as are knives, the next most deadly weapon that is frequently used in criminal attacks. Firearms robbery is about four times as likely to produce a victim death as a non-firearms robbery. 
In this section, I discuss what elements of gun use might increase the lethality of gun assaults and then briefly discuss the situation with gun versus non-gun robbery.

\section{The Causes of Differential Lethautry}

Guns may cause increases in the death rate from assault in a variety of different ways. The use of guns as opposed to other weapons in assault may be associated with both mechanical and social changes in violent assault that can increase its death rate. Among the mechanical or instrumentality aspects of gun use that can increase death rates are: the greater injurious impact of bullets; the longer range of firearms; and the greater capacity of firearms for executing multiple attacks. Among the features in social setting related to gun use are: the need to use more lethal instruments of assault in situations where an attacker fears that his adversary may have a gun, the need to sustain or intensify a deadly assault because an opponent possesses or is using firearms, and the increased willingness to use guns and other lethal weapons in personal conflict because such weapons are used generally. All of these aspects may increase the lethality of assaults committed with guns, but by no means to the same degree. There are also two social impacts of gun possession and use that can lower death rates: the deterrence of assaults because of fear of gun-owning victims and the prevention of attempted assaults by an armed victim.

In this paper, I will stress the most important of the mechanisms that increase death rates when guns are used, so-called instrumentality effects. For a summary of all these other potential causes and their assessment, see Zimring and Hawkins. ${ }^{3}$

\section{INSTRUMENTALTTY EFFECTS}

Of all the possible ways that gun use increases the deadliness of attacks, the theory that gunshot wounds inflict more damage than other methods of personal attacks is considered the most important and has been the subject of the most research. The early debate about the dangerousness of guns on deaths from assault involved different theories of the types of intention that produced assaults that lead to death. Marvin Wolfgang in his study of homicide doubted that the weapon used in an attack made much difference in the chance that a death would result since so many different weapons could produce death if an attacker tried hard enough. ${ }^{4}$ I responded to this assertion with a study of knife and gun assaults in Chicago. ${ }^{5}$

My data suggested that many homicides were the result of attacks apparently conducted with less than a single-minded intent to kill. Unlike the Wolfgang study where only fatal attacks were examined, the Zimring studies compared fatal and nonfatal gun and knife assaults in Chicago over four police periods in 1968 and gun assaults in 1972 . The studies found that 70 percent of all gun killings in Chicago were the result of attacks that resulted in only one wound to the victim, ${ }^{6}$ and that most attacks with guns or knives that killed a victim looked quite similar to the knife and gun attacks that did not kill.? From this data, I argued that most homicides were the result of ambiguously motivated assaults, so that the offender would risk his victim's death, but usually did not press on until death was assured.

Under such circumstances, the capacity of a weapon to inflict life-threatening injury would have an important influence on the death rate from assault. The 1968 Chicago study found that gun attacks were about five times as likely to kill as knife attacks, and this ratio held when the comparison was controlled for the number of wounds inflicted and the specific location of the most serious wound. ${ }^{8}$ Since knives were the next most deadly frequently used method of inflicting injury in attacks, the large difference in death rate suggested that substituting knives or other less dangerous instruments for guns would reduce the death rate from assault.

This weapon dangerousness comparison was first reported for Chicago in 1968 and has been replicated in other sites. ${ }^{9}$ The follow-up study demonstrated that a difference in weapon as subtle as firearm caliber can double the death rate from gun assaults. ${ }^{10}$ The summary conclusion from this line of research can be simply stated: the objective dangerousness of a weapon used in violent assaults appears to be a major influence on the number of victims who will die from attacks. This "instrumentality effect" is the major documented influence of guns on death rate. ${ }^{11}$

The use of guns in robbery is different from their use in woundings since the weapon is not necessarily used to inflict harm. Because robberies with guns frighten their victims into complying with the robbers' demands more often than other robberies, a smaller number of gun robberies result in woundings than personal force robberies and robberies with knives. Still, the greater dangerousness of guns when they are fired more than compensates for the lower number of wounds. For street robberies and those that take place in commercial establishments, the death rate for every 1,000 gun robberies is about three times that generated by robberies at knife point, and about ten times the death rate from robberies involving personal force. ${ }^{12}$

\section{Firearms as a Contributing Cause of Lethal Violence}

The use of firearms in assault and robbery is the single environmental feature of American society that is most clearly linked to the extraordinary death rate from interpersonal violence in the United States. But the strength of this relationship does not mean that firearms ownership and use has a simple, invariable, or independent influence on homicide rates. In this section, I consider the question of the 
causal connection between gun use and lethality. I do this not only because it is an important issue in relation to firearms and lethal violence, but also because reflecting on the questions of causation that arise in connection with firearms teaches us an important lesson about the role of many other environmental influences on the incidence of lethal violence.

The American debate about guns has produced one of the few causal critiques ever to appear on a bumper sticker: the famous slogan "Guns don't kill people, people kill people." Behind the strong sentiment that inspired this and a multitude of related appeals lies an important logical point. Firearms ownership and use is neither a necessary nor a sufficient cause of violent death in the United States. Firearms are not a necessary cause of killings because of the wide array of alternative methods of killing that are available ranging from the strangler's hands to car bombs. Even in the United States at the turn of the $21^{\text {st }}$ century, nearly 30 percent of all killings did not involve guns. Moreover, the widespread availability of firearms is not a sufficient condition for intentional homicide by a wide margin. Almost one-half of all American households own some kind of guns and it is estimated that one-quarter of all households own a handgun - the weapon used in more than three-quarters of all gun homicides. Yet only a small fraction of all gun owners become gun attackers. The logical point here is that guns do not become dangerous instruments of attack if they are not used in an attack.

If gun use is neither a necessary nor a sufficient cause of violent death, what is the proper descriptive label for the role gun use plays in deaths due to intentional injury? The most accurate label for the role of firearms in those cases of death and injury from intentional attacks in which they are used is contributing cause. Even where the availability of a gun plays no important role in the decision to commit an assault, the use of a gun can be an important contributing cause in the death and injury that results for gun attacks. When guns are used in a high proportion of such attacks, the death rate from violent attack will be high. Current evidence suggests that a combination of the ready availability of guns and the willingness to use maximum force in interpersonal conflict is the most important single contribution to the high U.S. death rate from violence. Our rate of assault is not exceptional; our death rate from assault is exceptional. ${ }^{13}$

The role of gun use as a contributing cause means that the net effect of firearms on violence will depend on the interaction of gun availability with other factors which influence the rate of violent assaults in a society and the willingness of people to use guns in such assaults. So the precise contribution of firearms to the death toll from violence is contingent on many other factors that may influence the number and character of violent attacks.

Some implications of this contingency deserve emphasis. Introducing 10,000 loaded handguns into a social environment where violent assault is a rare occurrence will not produce a large number of additional homicide deaths unless it also increases the rate of assault. The percentage increase in homicide might be considerable if guns become substitutes for less lethal weapons. But the additional number of killings would be small because of the low rate of attack. Introducing 10,000 handguns into an environment where rates of attack and willingness to use handguns in attack are both high is a change that would produce many more additional deaths. The net effect of guns depends on how they are likely to be used.

One corollary of viewing guns as an interactive and contributing cause to intentional homicide is that societies with low rates of violent assault will pay a lower price if they allow guns to be widely available than will societies with higher rates of violence. The sanguine sound bite encountered in American debates about guns is: "An armed society is a polite society. ${ }^{14}$ As stated on the bumper sticker, this does not seem particularly plausible, but it does seems likely that only a very polite society can be heavily armed without paying a high price.

The United States of 2004 is far from that polite society, although things are better now than they were as recently as 1994. Our considerable propensity for violent conflict would be a serious societal problem even if gun availability and use were low. But the very fact that the United States is a high-violence environment makes the contribution of gun use to the death toll from violence very much greater. When viewed in the light of the concept of contributing causation, the United States has both a violence problem and a gun problem, and each makes the other more deadly.

\section{Varieties of Firearms Control}

The objective of almost all forms of firearms control is to reduce the use of loaded guns in attacks and robberies and thus to reduce the death rate from crime. There turns out to be several different strategies of control, many different intensities of gun regulation, and many different contexts in which controls can be attempted. One common strategy is to prohibit dangerous uses of guns so that hundreds if not thousands of statutes prohibit concealed handguns from being carried at all, and from being taken into airports, churches, schools, and courthouses. Other "time, place and manner laws" prohibit shooting in city streets. The idea is that some settings are so dangerous that otherwise allowable weapons and uses should be prohibited.

One dispute about a "time, place and manner" regulation generated its own considerable literature in the late 1990s. John Lott provided an econometric study which argued that expanding the criteria for concealed weapons permits was associated with lower crime rates. ${ }^{15}$ Several published criticisms have undermined Lott's findings 
either by criticizing the quality of his multi-variate regression evidence ${ }^{16}$ or by counter-demonstrations using similar methodology. ${ }^{17}$ Because the impact of such laws on citizen gun carrying behavior and the use of guns in self defense has not been measured, the evidence that "shall issue" permit-to-carry laws has impact on crime rates is thin.

A second class of controls attempt to restrict danger ous users from obtaining and using guns. In federal law, convicted felons, youth, and certain diagnosed and previously institutionalized persons with emotional illnesses are excluded from being eligible to obtain weapons. This is the primary type of firearms control strategy in federal law and in most states.

A third approach is to try to exclude from general ownership particular types of guns that are too easily misused. Federal law has all but banned automatic weapons and sawed-off shotguns since 1934, and the Federal Gun Control Act of 1968 added "destructive devices" such as bazookas and hand grenades to the list of classes of weapon thought too dangerous for general ownership. ${ }^{18}$ In the late 1980 s, a controversy arose over semi-automatic weapons with large ammunition magazines - so-called assault weapons - which have been restricted in a variety of ways under different laws with different definitions. ${ }^{19}$ And special restrictions also exist in a few states and cities for handguns.

A "dangerous uses" approach tries to govern the use of guns without reference to the people who can possess them or the kind of guns that can be owned. A "dangerous user" strategy tries to segregate higher risk users without making any guns unavailable for the rest of the population. A "dangerous guns" strategy tries to restrict the general availability of certain types of guns. Every state and city has a mix of different laws - there are no examples in the United States of jurisdictions that rely on only one general approach and not any I know of with only one set of regulations.

\section{Can Gun Control Work?}

The answer to this general question is a highly qualified "yes, but." If and to the extent that regulation reduces the use of loaded guns in crimes it will save American lives. But reducing the share of violence with guns is not an easy task to achieve in urban environments with large inventories of available handguns. Most gun control efforts do not make measurable impacts on gun use, particularly low budget symbolic legislation. If Congress when creating what it called a "gun-free school zone" by legislation did reduce firearms violence, the result would be on a par with that of the miracle of loaves and the fishes. But New York City's effort to tightly enforce one of the nation's most restrictive handgun laws did apparently have a substantial payoff in reduced shootings that saved many lives. ${ }^{20}$
What I would emphasize here is the fallacy of categorical generalizations. We have no business asking whether broad classes of laws - criminal prohibitions, anti-theft statutes or gun control strategies - work or don't. That is an aggregation error as long as guns are a contributing cause to the death rate from violent crime in the United States. The serious work is in identifying the specific strategies and contexts in which regulation can reduce the use of firearms in violent assault and attempting to achieve these results at tolerable public and personal cost.

\section{REFERENCES}

1. J. B. Jacobs, Can Gun Control Work? (New York: Oxford University Press, 2002).

2. F. E. Zimring and G. Hawkins, Crime Is Not the Problem: Lethal Violence in America (New York: Oxford University Press, 1997): at 108.

3. See Zimring and Hawkins, supra note 2: 113-122.

4. M. Wolfgang, Patterns in Criminal Homicide (Philadelphia: University of Pennsylvania Press, 1958).

5. F. E. Zimring, "Is Gun Control Likely to Reduce Violent Killings?" University of Chicago Law Review 35 (1968):721-737

6. F. E. Zimring, "The Medium is the Message: Firearms Caliber as a Determinant of the Death Rate from Assault," Journal of Legal Studies 1 (1972): 97-123.

7. See Zimring, supra note 5.

8. Zimring, supra note 5.

9. T. Vinson, "Gun and Knife Attacks," Australian Journal of Forensic Sciences 7 (1974): 76; R. Sarvesvaran and C.H.S. Jayewardene,. "The Role of the Weapon in the Homicide Drama," Medicine and Law 4 (1985): 315- 326.

10. Zimring, supra note 6 .

11. P. J. Cook, "The Technology of Personal Violence," in M. Tonry, ed., Crime and Justice: A Review of Research (Chicago: Chicago University Press., 1991).

12. F. E. Zimring and J. Zuehl, "Victim Injury and Death in Urban Robbery: A Chicago Study," Journal of Legal Studies 15 (1986):1-40; Cook supra note 11: 17.

13. Zimring and Hawkins, supra note 2: 34-50

14. Handgun Control Inc., Carrying Concealed Weapons: Questions and Answers (Washington, D.C.: Handgun Control Inc., 1995).

15. J. R. Lott, More Guns, Less Crime (second edition) (Chicago: University of Chicago Press, 2000).

16. D. Black and D. Nagin, "Do 'Right-to-Carry' Laws Deter Violent Crime?" Journal of Legal Studies 27 (1998): 209- 219; F. E. Zimring and G. Hawkins, "Concealed Handguns: The Counterfeit Deterrent," The Responsive Community 7 (1997): 46-60.

17. J. Donohue and I. Ayers, "Shooting Down the More Guns, Less Crime Hypothesis," National Bureau of Economic Research (working paper no. w9336, 2002); J. Donohue and I. Ayers, "The Latest Misfires in Support of the More Guns, Less Crime Hypothesis," Stanford Law Review 55 (2003):1371-1398.

18. F. E. Zimring, "Firearms and Federal Law: The Gun Control Act of 1968," Journal of Legal Studies 4 (1975): 133-198.

19. F. E. Zimring, "The Problem of Assault Firearms," Crime and Delinquency 35 (1989): 538-545.

20. J. Fagan, F. E. Zimring, and J. Kim, "Declining Homicide in New York City: A Tale of Two Trends," Journal of Criminal Law and Criminology 88 (1998): 1277-1323. 